\title{
Delineation, characteristic and classification of soils containing carbonates in plow horizons within young moraine areas
}

\author{
Paulina Matecka, Marcin Świtoniak ${ }^{1, *}$ \\ 1 Nicolaus Copernicus University in Toruń, Department of Soil Science and Landscape Management, 1 Lwowska Str., 87-100 Toruń, Poland \\ * Dr hab. Marcin Świtoniak, prof. UMK, swit@umk.pl, ORCID iD: https://orcid.org/0000-0002-9907-7088
}

\author{
Received: July 24, 2019 \\ Accepted: January 31, 2020 \\ Associated editor: W. Szymański
}

\section{Keywords}

Orthophotomaps

Soil erosion

Calcareous soils

Regosols

\begin{abstract}
Soil erosion, as a result of which physical, chemical and morphological features of the soil are changing, is an increasingly common problem. The outcropping of deeper horizons of pedons also causes a change in the colour of their surface horizons, which is reflected in aerial photos. Strongly exposed to erosive transformations are agricultural areas. Intensive human activity leads to an increase in ratio of natural slope processes and the movement of soil material by agricultural machinery, which is called human-induced erosion or denudation. The largest transformations within study area - the Chełmża commune, can be observed at the tops of convex hills, where the plow horizons of the strongly truncated soils are mixed with the calcareous parent material (glacial tills). The aim of this study was to determine spatial extent of soils that contain calcium carbonate in plow horizons, based on available orthophotomaps and cartographic materials - topographic maps and a numerical terrain model. More than 700 contours (about 1\% of investigated area) of eroded soils potentially rich in the calcium carbonate were delimited. The following criteria were taken into account: 1) very bright brown colour of surface horizons indicating the potential presence of calcium carbonate; 2) proximity of strongly eroded clay-illuvial soils characterized by a dark brown color of surface horizons indicating the exposure on surface of argik horizons; 3) occurrence in places exposed to erosion - on tops of hills and within convex slopes. Field works and laboratory analysis allowed to verification of the contours of potentially calcareous soils. These studies confirmed the high suitability of aerial photos in delimitation of mentioned pedons - $96 \%$ of the analysed profiles represented strongly eroded calcareous soils. The average content of $\mathrm{CaCO}_{3}$ in plow horizons was $6.1 \%$. The only genetic horizons of the studied soils are weakly developed A horizons lying directly on parent material. Plow horizons did not meet the criteria referring to colour and/or carbon content of mollik and parent material had too low a calcium carbonate content to designate kalcik horizons. According to the Polish Soils Classification (2019), most of the analysed soils can be classified as weakly developed soils - typical/humic regosols. In one case, due to the strong influence of ground water, the profile was classified as gleysol. The review of archival materials focused on eroded calcareous soils indicates the possibility of occurrence of mollik or/and kalcik horizons and what is connected with it - chernozems, black earths and stagnosols.
\end{abstract}

\section{Introduction}

Issues related to soil erosion, leading to changes in physical, chemical and morphological features of the soil are more and more frequently discussed in the scientific literature (Van Oost et al., 2003; De Alba et al., 2004; Marcinek and Komisarek, 2004; Leopold and Völkel, 2007; Martinez-Casasnovas and Ramos, 2009; Dreibrodt et al., 2010; Kittel, 2014; Deumlich et al., 2010, 2018). Particularly exposed to erosive transformations are hilly and undulating agricultural areas, where long-lasting lack of vegetation cover and agrotechnical treatments, mainly plowing, intensify natural slope processes. As a result, soil material is washed away or moves during the cultivation down the slope, what is called anthropogenic (human-induced) denudation (Sinkiewicz, 1998) or accelerated erosion (Evans, 1993). The effect of anthropogenic denudation is the progressive shallowing (truncation) of the soil profiles located in upper, convex part of slopes, leading to disappearance of genetic horizons, as well as increasing the thickness of the colluvial material in the depressions and at the foot slope positions (e.g. Turski et al., 1991; Marcinek and Komisarek, 2004; Klimowicz and Uziak, 2001; Świtoniak, 2014; Świtoniak, 2015). The degree and extent of erosional transformations as well as 
the rate and loss of soil material are diverse. The truncation of profiles is dependent on inclination, exposure and shape of slopes, soil susceptibility to erosion, land use and many other factors (Sinkiewicz, 1998; Paluszek, 2010; Podlasiński, 2013; Świtoniak, 2014; Deumlich et al., 2010, 2018).

The most intensive studies on soil erosion in Poland were conducted mainly in mountainous and upland areas (e.g. Turski et al., 1987; Józefaciuk and Józefaciuk, 1996; Paluszek, 1994, 2010). The first papers focused on the Polish Lowlands were published, among others by Chudecki (1960) and Uggla et al. (1968). Since the end of the nineties of the 20-th century the studies on erosion of the most common moraine upland pedons - clay-illuviated soils (Luvisols or Retisols in WRB (IUSS, 2015)) have been intensified. This phenomenon was studied by Sinkiewicz (1998), Bednarek and Szrejder (2004) within Chełmno morainic plateau, Bednarek et al. (2009) on Świecie plateau or Świtoniak (2014) within area of Brodnica Lakeland and on borders of morainic plateaus with huge river valleys (Świtoniak et al., 2015, 2018). In the analyzed area of the Chełmno morainic plateau, clay-illuviated soils were strongly truncated to the argik horizon (Bednarek and Szrejder, 2004), and their morphology is similar to brown soils (PSG, 2019) or Cambisols according to WRB (Świtoniak et al., 2016). In places with significant denivelations and heavily exposed to the slope processes, soil truncation leads to the outcropping of the former parent material - calcareous glacial till (Świtoniak et al., 2013; Świtoniak, 2014). As a result strongly eroded soils with simple sequence of soil horizons Apk-Ck and calcium carbonate in plow horizons (Apk) were developed.

Traditional methods for determining the degree and extent of soil erosion based mainly on the analysis of agricultural soil maps, topographic, geological maps etc. in combination with workand time-consuming detailed field work seems to be insufficient. Although the transformations related to human-induced erosion in the soil cover of young morainic areas of north Poland are significant, there is lack of cartographic units on the agricultural soils maps associated with the discussed phenomenon (Pindral and Świtoniak, 2017). Therefore many researchers state that it is necessary to reclassify and update agricultural soil maps (Kobierski, 2013), and then to determine the extent of erosional transformations. The updated results should be correlated with orthophotomaps (Przewoźna, 2012). Since the 1960s, the recognition of variability of soil properties on the basis of aerial photographs has grown rapidly. Many researchers dealt with this issue and described the methods of aerial photo interpretation e.g. Buringh (1970), Białousz (1978), Białousz et al. (1978), Sinkiewicz (1998), Žížala et al. (2019). The aerial photos are a very useful tool for interpreting the extent and degree of eroded soils due to the shallowing of the soil profile, physical and physicochemical properties of surface horizons and their spectral response are changing too (Świtoniak et al., 2013). For example, according to Gacki and Gołębiewski (1977) decreasing the amount of humus on the eroded slope leads to a reduction in the optical density, which is manifested in a lighter phototon in the aerial photos.

The present study aims to assess the possibility of using aerial photographs in delineation of the contours of pedons containing calcium carbonate in plow horizons (hereafter in brief called "calcareous soils"), which are the most eroded and weakly devel- oped soils within young moraine areas. This goal was achieved through the following research tasks:

1) preliminary delineation of potentially calcareous soil contours on the basis of the adopted key with the use of a easily accessible orthophotomaps;

2) field validation of designated contours;

3) determination of basic physical and chemical properties of the studied soils, their profile morphology and systematic position.

\section{Study area and methods}

The study was carried out in the Chełmża commune. This area was chosen due to diversity of terrain denivelation and intensive agricultural use (two factors leading to widespread erosional soil changes) as well as dominance of moraine uplands in which clay-illuvial soils predominate and are potentially truncated in some locations to the depth of the carbonate-rich parent materials Ck (glacial tills).

In administrative terms, the commune is located in the Torun poviat in the central part of the Kuyavian-Pomeranian Voivodeship (Fig. 1). According to the division of Poland into physiogeographic regions, the analyzed area is located in the Chełmno Lake District mesoregion (Kondracki, 2009). It borders with the Drwęca Valley and the Bodnica Lake District in the east, the Torun Basin in the south, the Fordon Valley and the Grudziądz Basin in the west and the Iława Lake District in the north (Kondracki, 2009; Solon et al., 2018).

Average annual air temperature (based on data from period 1951-1970) in the studied area is $7,5^{\circ} \mathrm{C}$ (Wójcik and Marciniak, 1987a). The warmest month is July with average air temperature of $17,5^{\circ} \mathrm{C}$, and the coldest month is February with average air temperature of $-3,3^{\circ} \mathrm{C}$. The average annual precipitation in the Chełmno Lake District is $519 \mathrm{~mm}$ with the majority of precipitation occurring in summer and the maximum in July - $101 \mathrm{~mm}$ (Wójcik and Marciniak, 1987b). The humid period with precipitation-evaporation ratio $>1$ lasts for a whole year conditioning the leaching soil-water regime in pedons with good natural drainage.

Relief of the studied area is very diverse (Fig. 2) and has all the features of the young glacial (inherited from the last glaciation) landscape. The study area is located within the range of Pomeranian phase of the Weichselian glaciation (Niewiarowski, 1959), which left deposits of morainic glacial tills or fluvioglacial sands and gravels in the analyzed area. The average elevation of the Chełmno morainic plateau increases from the south, on contact with the Torun Basin from $85 \mathrm{~m}$ a.s.l. up to 90-95 m a.s.l. towards east and north (Niewiarowski and Weckwerth, 2006). The altitude of the analyzed area varies from 75 to $111 \mathrm{~m}$, and the maximum denivelations are $36 \mathrm{~m}$. The most varied terrain with the inclination of slopes between $2^{\circ}-10^{\circ}$ is typical for hilly and undulating moraine plateau in the north-eastern part of the area. The relief of the southern part of the analyzed area has a completely different character. There is the lowest point of the area (75 $\mathrm{m}$ n.p.m.), in the place where the flat morainic plateau is cut by subglacial tunnel valley (Fig. 2) with slope inclination even up to $13^{\circ}$. Bottom part of tunnel valley is occupied by many post-glacial lakes elongated in shape, including the largest in the 
Fig. 1. Location of study area

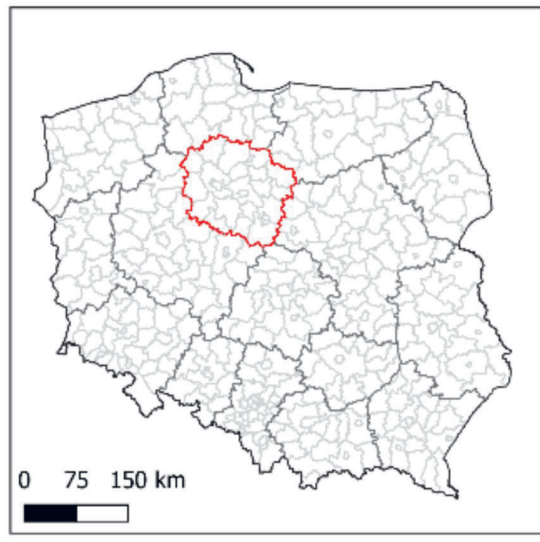

Legend

Chełmża commune

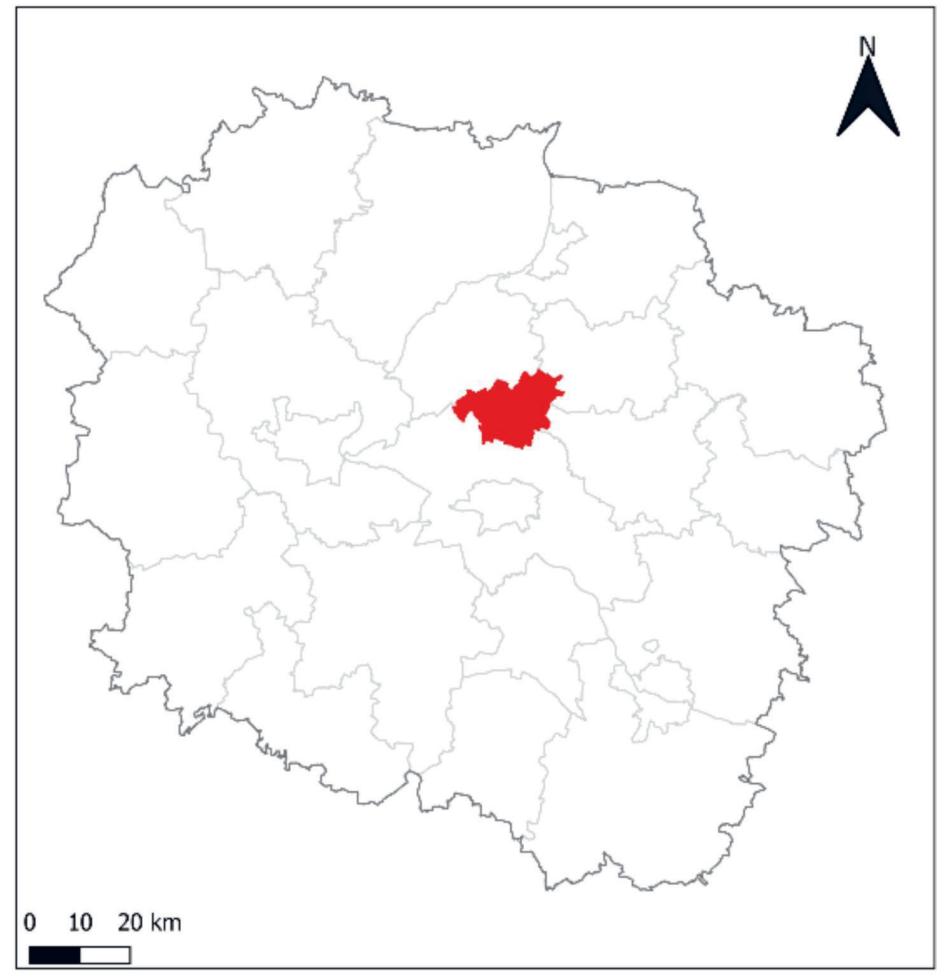

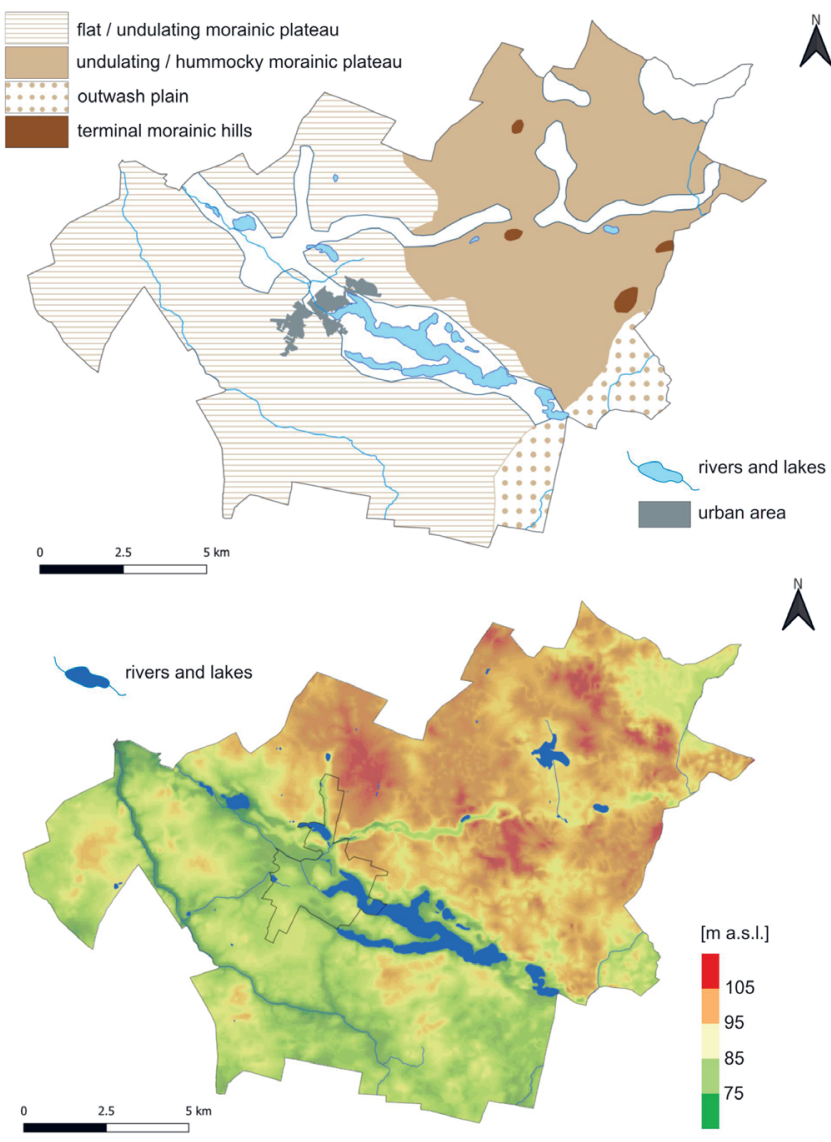

Fig. 2. Geomorphology (Niewiarowski, 1959) and relief (DTM). area - Chełmżyńskie Lake, the river Fryba, and Holocene organic deposits (peats). The described valley has a NW-SE direction, which matches to entire late Pleistocene drainage system of the region - the ice marginal Drwęca Valley (they are perpendicular) and the tunnel valleys of Dobrzyń Lake District (Wysota, 1993). The fluvioglacial sands and gravels formed the Chełmża outwash plain, stretching in the form of a strip along the tunnel valley described above.

The dominant parent materials of soils in the studied area are glacial tills and fluvioglacial as well as glacial sands deposited during the last glaciation. Holocene sediments occupy relatively small areas. Clay-illuviated soils (PSC, 2019) or according to WRB Luvisols and Retisols (IUSS, 2015) cover $66 \%$ of the studied area. As a result of erosive shallowing of pedons, the primeval humus and eluvial horizons have been destroyed in many places, and the present sequence of horizons (A-Bt-Ck) resembles the brown soils (PSC, 2019) or Cambisols (IUSS, 2015) morphology (Bednarek and Szrejder, 2004; Świtoniak et al., 2016). In places with limited natural drainage, semihydrogenic black earths (PSC, 2019) - Mollic Gleysols or Gleyic Chernozems according to WRB (IUSS, 2015) were also developed from glacial deposits. Calcareous sandy loams or loams are parent materials of these soils (Bednarek and Jankowski, 2006). They occupy a substantial area (18\%) of the studied region. The largest contours of black earths occur in the southern part of the area within the flat morainic plateau. Smaller, but numerous spots of these soils were developed within bottom parts of terrain depressions of the hilly and undulating moraine plateaus in the entire area. From the fluvioglacial sands, rusty soils (PSC, 2019) / Brunic Arenosols (IUSS, 2015) were formed. Such soils constitute $5 \%$ of the area. Organic soils (Histosols in WRB) occur in bottom of tunnel valley and in some local depressions. 


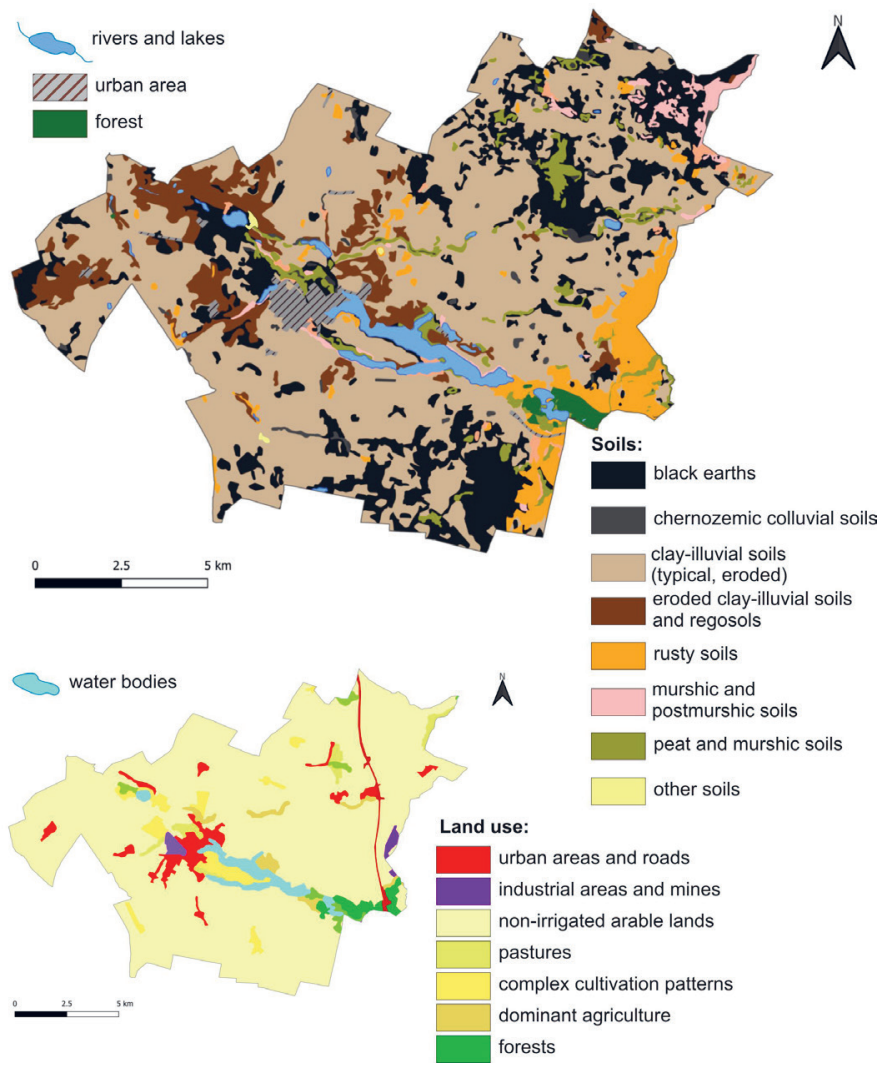

Fig. 3. Soil cover (according to soil agricultural maps 1:25 000) and land use (according to Corine Land Cover 2012).

Forms of land use are typical for whole Chełmno Lake District mesoregion. Agricultural land covers $89 \%$ of the area with predominant arable land - 83\% (Fig. 3). Due to the relatively high soil fertility and favorable relief, this area has been used for agricultural purposes since 7th-8th century (Chudziak, 1990). Forests covering about $1.5 \%$ of the area remained only on the less fertile soils (unsuitable for agriculture), which were developed mainly from fluvioglacial sands.

Based on the collected cartographic materials (topographic map, agricultural soil map $1: 25.000$, DTM) and accessible orthophotomaps (https://www.google.pl/maps; www.geoportal.gov.pl), the contours of soils that could contain calcium carbonate in plow horizons were pre-determined. Delimitation of the contours was made with the QGis software tools. About 35\% of the entire area was suitable for the analysis - plots of arable land, where photointerpretation was possible based on the colour of surface horizons without vegetation coverage (Fig. 4). More than 700 contours representing approximately $1 \%$ of the analyzed area were selected for further testing. The selected contours met the following criteria: i) light colour of surface horizons (from light brown to almost white), which indicates the potential presence of calcium carbonate; ii) surroundings by "rings" of eroded clay-illuvial soils that were characterized by a dark brown color in the photos resulting from the outcropping on surface Bt horizons; iii) occurrence in places particularly exposed to erosion, i.e. on hillsides and within convex parts of slopes (Fig. 4).
From among the 700 contours, 50 field validation sites were randomly selected. In these points the verification of the presence of calcium carbonate with $1 \mathrm{M} \mathrm{HCl}$ in plow horizons was made during field work. In addition, soil samples were taken from plow and sub-plow horizons in 16 places to determine their properties in laboratory. Standard soil analyses were performed using the methods as follows: total organic carbon (TOC) content by Tiurin's method; total nitrogen content by Kjeldahl method; $\mathrm{CaCO}_{3}$ content - volumetric Scheibler method; particle-size distribution - by sieve and sedimentary aerometric method; $\mathrm{pH}$ of soil-to-solution ratio of $1: 2.5$ using $1 \mathrm{M} \mathrm{KCl}$ and distilled $\mathrm{H}_{2} \mathrm{O}$ as the suspension medium. Color has been described according to Munsell Soil Color Charts (2000).

The systematic position and symbols/names of diagnostic horizons were given after the sixth edition of the Polish Soil Classification (PSC 2019) and WRB (IUSS 2015). English-language names of soil units (PSC 2019) were given as proposed by Kabała et al. (2019).

\section{Results}

Almost all analyzed soil profiles were characterized by a very simple sequence of genetic horizons (Fig. 5, Table 1) with plow Ap overlying directly the parent material Ck. Lack of any eluvial or illuvial horizons was noticed in whole group of the analyzed soils, and only in one case (Profile 1) the parent material had gleyic features connected with groundwater influence. Solum was limited to the thickness of plow horizon, whose lower abrupt boundary was at a maximum depth of about $30 \mathrm{~cm}$. In terms of texture, various granulometric groups of loams dominated both in Ap horizons and in parent materials. The vast majority of surface horizons had sandy loam texture. Clay fraction content in Ap horizons ranged from $7 \%$ to $24 \%$ (mean $17 \%, S D \pm 4.6$ ). The parent material of the studied soils were texturally slightly more diverse from clay loam containing $34 \%$ of clay fraction to very fine sandy loam with a small amount of clay (4\%) (mean 16\%, SD \pm 7.3 ). Only one soil sample (a deeper material lithologically different from parent material in profile 16) had texture of very fine loamy sand with almost $90 \%$ of the sand fraction content.

In surface horizons, the mean organic carbon content (Table 2) was $0.63 \%$ ( $\mathrm{SD} \pm 0.14$, values from $0.38 \%$ to $0.85 \%$ ), while the $\mathrm{C} / \mathrm{N}$ ratio was narrow, on average 8 (ranged from 7 to 9 ).

Almost all investigated soils contained calcium carbonate (Table 2), whose average content in Apk horizons was $5.8 \%$ $(\mathrm{SD} \pm 3.2)$ and individual values were in the range of $0.41 \%$ (Profile 4 ) and $9.91 \%$ (Profile 3 ). In the parent materials, its content was even higher reaching 13.8\% (mean 10.2, SD \pm 3.8 ) (Profile 1). Calcium carbonate occurred both in dispersed and concentrated forms. They are especially well visible macroscopically in parent materials in form of concretions, nodules, pseudomycelia or infillings. Secondary carbonates in Ap horizons usually have only the character of chaotically arranged, disturbed concretions. The reaction of both calcareous Ap horizons and parent materials is alkaline and the $\mathrm{pH}_{\mathrm{H}_{2} \mathrm{O}}$ values range from 7.8 to 8.9 ( $\mathrm{pH}_{\mathrm{KCl}} 7.1-8.4$ ). An exception is Profile 13, where no calcium carbonate has been 


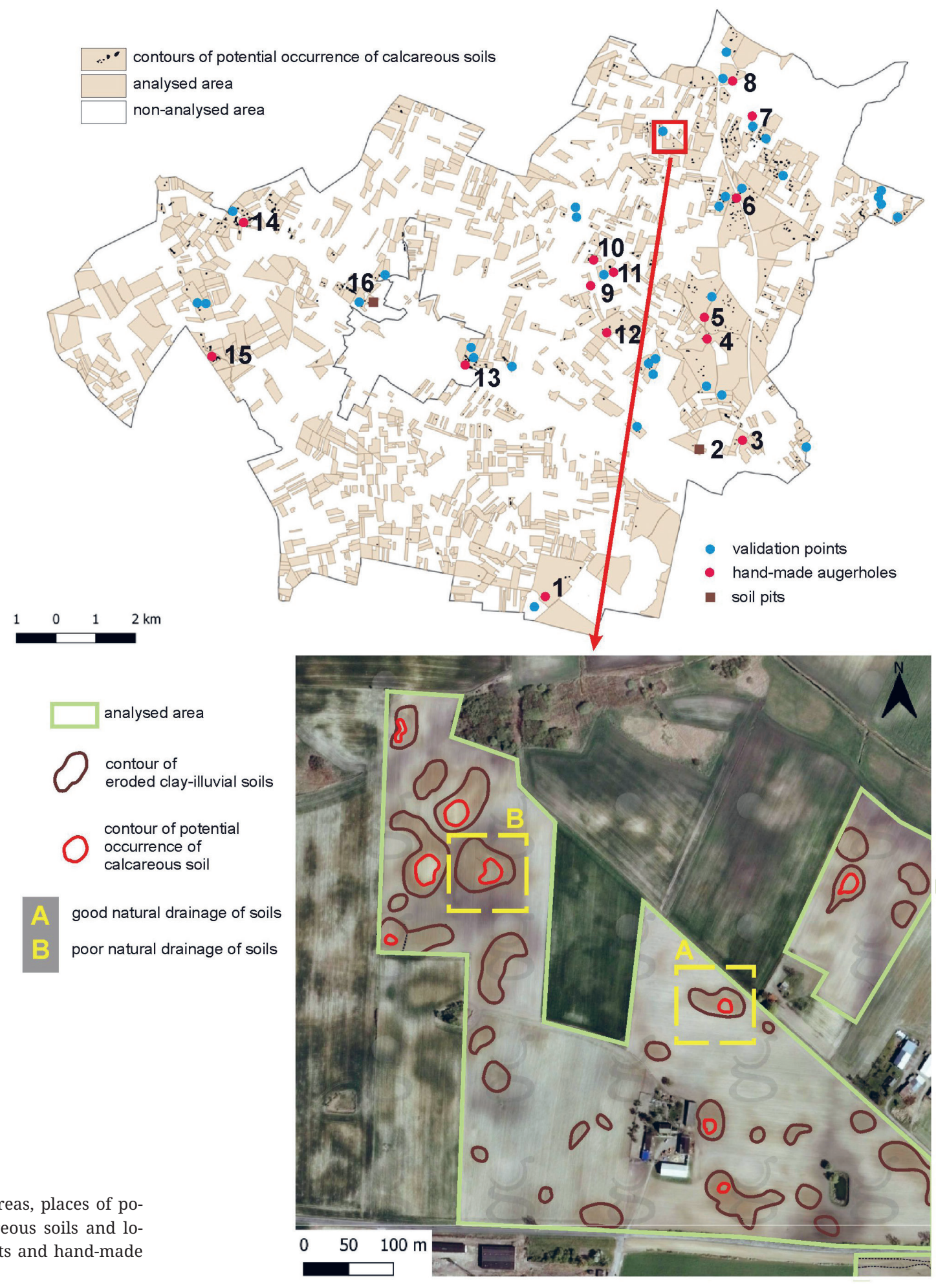

Fig. 4. Extent of analyzed areas, places of potential occurrence of calcareous soils and location of study sites (soil pits and hand-made augerholes)

Profile 13) there was no detectable visible or audible effervescence of soil material with acid.

The color of the surface levels was usually brown (10YR 5/3 dry, 10YR 4/3 wet) and only slightly differs compared to the parent materials where yellowish-brown or pale brown color predominates (10YR 6/3 dry, 10YR 5/4 wet). zons by field measurement with $1 \mathrm{M} \mathrm{HCl}$, were mostly calcareous.

The length and intensity of acid reaction (effervescence) indicate of $2-15 \%$ of calcium carbonate content. Only in one case (near 
Fig. 5. Typical morphology of investigated soils

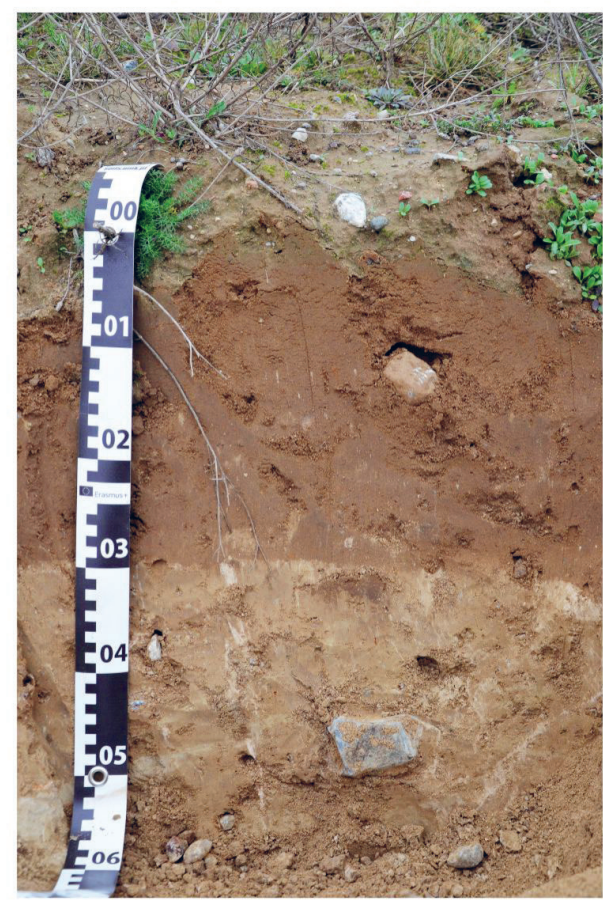

\section{Discussion}

In the whole group of the 50 analyzed sites (soil pits, augerholes and surface validation measurements) only in two cases soil material in plow horizons was non-calcareous. The obtained results indicate the high (96\%) effectiveness of the preliminary interpretation key for aerial images prepared for the Brodnica Lakeland, which is very useful to determine the occurrence of calcareous soils (Świtoniak et al., 2013). The reason for the lack of calcium carbonate in the Profile 13 (and lying near to it the one of validation point) may be the different (than glacial tills) lithological character of the sediment. The mentioned non-carbonate soils were located in the edge zone of the morainic upland on contact with the tunnel valley and are probably developed from fluvioglacial deposits characterized by bright colour. Similar texture with a high content of sand fraction was also found in horizon 2C containing fluvioglacial sand covered by loamy material in Profile 16 located in upper slope of tunnel valley. The all others studied soils had the texture typical for glacial tills of moraine plateaus (Bednarek and Prusinkiewicz, 1997). The content of calcium carbonate in the analyzed pedons was very diverse - both in plow horizons and parent materials (Table 2). The main factor conditioning this diversity is probably the natural primary heterogeneity of glacial tills (Bednarek and Prusinkiewicz, 1997). It was confirmed by the research of other authors, e.g. Kobierski (2013) noticed in the parent materials (Ck) of clay-illuviated soils of Krajna, Chodzież and Chełmno Lake District $\mathrm{CaCO}_{3}$ content from $6.5 \%$ to $10.9 \%$. In similar morainic soils of the Brodnica Lake District this variability is even greater and ranges between $0.6 \%$ and 9.1\% (Świtoniak, 2014). In addition, the parent materials of the studied soils contain a considerable number of secondary forms of $\mathrm{CaCO}_{3}$ that affect even greater variation in the content of carbonates in the soil material. It should be noted that the highest content of $\mathrm{CaCO}_{3}$ was recorded in Profile 1 where parent

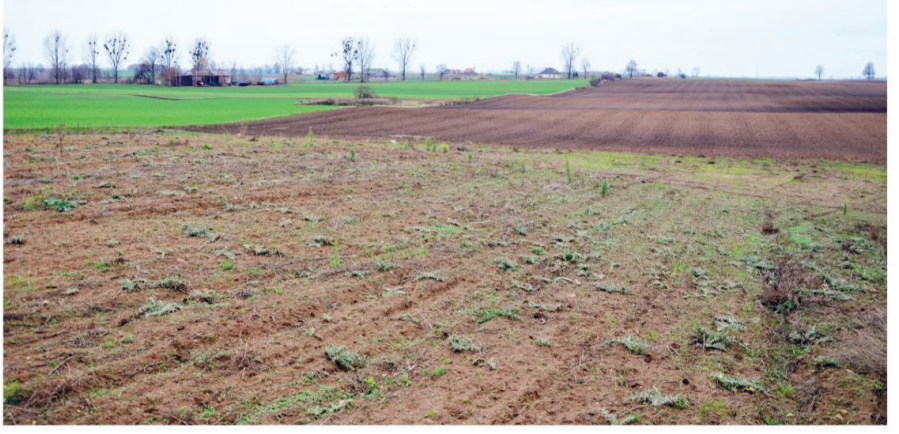

Apk - 0-30 cm, plough humus horizon, sandy loam, brown (10YR $5 / 3 ; 10 Y R 4 / 3$ ), slightly moist, moderate subangular medium/coarse structure, very fine or fine roots, few carbonates, abrupt smooth boundary;

Ck - 30-(60) cm, parent material with protocalcic properties, sandy loam, yellowish brown (10YR 7/3; 10YR 5/4), slightly moist, strong subangular coarse structure, very fine and very few roots, common fine rounded soft concretions and pseudomycelium of secondary carbonates.

material was affected by groundwater that could limit the leaching of carbonates outside the soil profile or even could enrich top of soil in carbonates due capillary rising and evaporation.

The contours of the discussed calcareous soils were easily identifiable and delineable due to their high contrast in relation to the surrounding dark brown outcrops of argik horizons (Świtoniak et al., 2013). The contours were usually small, i.e. on average slightly below 0.1 ha and their shape referred to the summits of moraine hills. Slightly larger sizes reached longitudinal contours covered the upper, convex parts of the valley slopes. Despite the small size compared to the contours of other soils, they were numerous (over 700 in the analyzed area) and cover about $1 \%$ of the entire soil cover of the study area. It should be noted that on the agricultural soil maps this type of cartographic units were completely neglected (Świtoniak et al., 2016; Pindral and Świtoniak, 2017). It seems to be a serious mistake, because the exposure of the calcareous material on the terrain surface of the upper slopes have great importance not only to the place where they occur. They are changing the functioning of entire soil catenas e.g. can lead to inversion of genetic horizons by washing the soil material downslope. Moreover it can increase the $\mathrm{pH}$ value of all soils located along slope through the lateral, gravitational migration of waters rich in dissolved calcium carbonate (Sommer and Schlichting, 1997).

The presence of calcium carbonate in the plow horizons of the studied soils is largely associated with the strong impact of slope processes on the soil cover. The outcropping of the calcareous parent material results from the erosional shallowing of the soils with a substantially larger primary thickness of solum. The vast majority of authors interpret the soils of moraine uplands with the sequence of Ap-Ck horizons as the strongest stage of truncation of primeval clay-illuviated soils. These conclusions were reached, among others, by Sinkiewicz (1998) in many regions of north Poland, Koćmit et al. (2001) within West Pomera- 
Table 1.

Texture of the studied soils

\begin{tabular}{|c|c|c|c|c|c|c|c|c|}
\hline \multirow[b]{2}{*}{ Profile } & \multirow[b]{2}{*}{ Horizon } & \multirow[b]{2}{*}{ Depth [cm] } & \multicolumn{4}{|c|}{ Percentage share of fraction, size of fraction in $\mathrm{mm}$} & \multicolumn{2}{|c|}{ Textural class } \\
\hline & & & $\begin{array}{l}\text { Gravel } \\
(>2.0)\end{array}$ & $\begin{array}{l}\text { Sand } \\
(2.0-0.05)\end{array}$ & $\begin{array}{l}\text { Silt } \\
(0.05-0.002)\end{array}$ & $\begin{array}{l}\text { Clay } \\
(<0.002)\end{array}$ & $\begin{array}{l}\text { PTG } \\
2008\end{array}$ & USDA \\
\hline \multirow[t]{2}{*}{1} & Apk & $0-30$ & 6 & 59 & 24 & 17 & gl & SL \\
\hline & Ckg & $30-(60)$ & 5 & 59 & 23 & 18 & $\mathrm{gl}$ & SL \\
\hline \multirow[t]{2}{*}{2} & Apk & $0-30$ & 5 & 72 & 19 & 9 & gpdr & SL \\
\hline & $\mathrm{Ck}$ & $30-(60)$ & 5 & 64 & 27 & 9 & $\mathrm{gl}$ & SL \\
\hline \multirow[t]{2}{*}{3} & Apk & $0-30$ & 4 & 60 & 25 & 15 & $\mathrm{gl}$ & SL \\
\hline & $\mathrm{Ck}$ & $30-(60)$ & 3 & 58 & 26 & 16 & $\mathrm{gl}$ & SL \\
\hline \multirow[t]{2}{*}{4} & Apk & $0-30$ & 2 & 60 & 26 & 14 & $\mathrm{gl}$ & SL \\
\hline & $\mathrm{Ck}$ & $30-(60)$ & 3 & 58 & 23 & 19 & $\mathrm{gl}$ & SL \\
\hline \multirow[t]{2}{*}{5} & Apk & $0-30$ & 4 & 59 & 22 & 19 & gl & SL \\
\hline & $\mathrm{Ck}$ & $30-(60)$ & 4 & 61 & 23 & 16 & $\mathrm{gl}$ & SL \\
\hline \multirow[t]{2}{*}{6} & Apk & $0-30$ & 4 & 56 & 24 & 20 & $\mathrm{gl}$ & SCL \\
\hline & $\mathrm{Ck}$ & $30-(60)$ & 5 & 54 & 25 & 21 & gpi & SCL \\
\hline \multirow[t]{2}{*}{7} & Apk & $0-30$ & 8 & 57 & 19 & 24 & gpi & SCL \\
\hline & $\mathrm{Ck}$ & $30-(60)$ & 4 & 39 & 27 & 34 & gi & $\mathrm{CL}$ \\
\hline \multirow[t]{2}{*}{8} & Apk & $0-30$ & 2 & 52 & 29 & 19 & $\mathrm{gl}$ & $\mathrm{L}$ \\
\hline & $\mathrm{Ck}$ & $30-(60)$ & 2 & 43 & 32 & 25 & gz & $\mathrm{L}$ \\
\hline \multirow[t]{2}{*}{9} & Apk & $0-30$ & 8 & 58 & 23 & 19 & $\mathrm{gl}$ & SL \\
\hline & $\mathrm{Ck}$ & $30-(60)$ & 4 & 58 & 24 & 18 & $\mathrm{gl}$ & SL \\
\hline \multirow[t]{2}{*}{10} & Apk & $0-30$ & 3 & 61 & 22 & 17 & $\mathrm{gl}$ & SL \\
\hline & $\mathrm{Ck}$ & $30-(60)$ & 2 & 61 & 24 & 15 & $\mathrm{gl}$ & SL \\
\hline \multirow[t]{2}{*}{11} & Apk & $0-30$ & 3 & 58 & 26 & 16 & $\mathrm{gl}$ & SL \\
\hline & $\mathrm{Ck}$ & $30-(60)$ & 7 & 59 & 24 & 17 & $\mathrm{gl}$ & SL \\
\hline \multirow[t]{2}{*}{12} & Apk & $0-30$ & 7 & 59 & 23 & 18 & $\mathrm{gl}$ & SL \\
\hline & $\mathrm{Ck}$ & $30-(60)$ & 3 & 59 & 25 & 16 & $\mathrm{gl}$ & SL \\
\hline \multirow[t]{2}{*}{13} & Ap & $0-30$ & 1 & 71 & 22 & 7 & gpdr & FSL \\
\hline & C & $30-(60)$ & 1 & 65 & 31 & 4 & gpbdr & FSL \\
\hline \multirow[t]{2}{*}{14} & Apk & $0-30$ & 0 & 49 & 35 & 16 & $\mathrm{gz}$ & $\mathrm{L}$ \\
\hline & $\mathrm{Ck}$ & $30-(60)$ & 0 & 53 & 34 & 13 & $\mathrm{gl}$ & SL \\
\hline \multirow[t]{2}{*}{15} & Apk & $0-30$ & 3 & 46 & 32 & 22 & $\mathrm{gz}$ & $\mathrm{L}$ \\
\hline & $\mathrm{Ck}$ & $30-(60)$ & 3 & 44 & 35 & 21 & gz & $\mathrm{L}$ \\
\hline \multirow[t]{3}{*}{16} & Apk & $0-20$ & 1 & 67 & 23 & 10 & gpdr & FSL \\
\hline & $\mathrm{Ck}$ & $20-40$ & 2 & 66 & 23 & 11 & gpdr & FSL \\
\hline & $2 \mathrm{Ck}$ & $40-(60)$ & 0 & 89 & 7 & 4 & pgbdr & FS \\
\hline
\end{tabular}

gl - glina lekka, gpdr - glina piaszczysta drobnoziarnista, gpbdr - glina piaszczysta bardzo drobnoziarnista, gpi - glina piaszczysto-ilasta, gz - glina zwykła, SL - sandy loam, SCL - sandy clay loam, CL - clay loam, L - loam, FSL - fine sandy loam, FS - fine sand.

nia, Bednarek and Szrejder (2004) in the Chełmno Lake District, Podlasiński (2013) in the Wełtyń Plain and Świtoniak (2014) in Brodnica Lake District. Similar phenomena of soil truncation and outcropping the calcareous parent material on the terrain surface were also recorded in the post-glacial morainic areas of Mecklenburg and Brandenburg (Deumlich et al., 2010, 2018) and in loess regions - in the Lublin Upland (Klimowicz and Uziak, 2001), in Hungary (Novák et al., 2018) or in the Czech Republic (Penížek et al., 2018; Žížala et al., 2019). Such a significant amount of well-preserved concentrations of secondary carbonates could not be formed directly below the plow horizons. In areas not affected by groundwater and therefore exposed to leaching by 
rainwater, there would be a rapid decalcification of moraine material, the initiation of the lessiváge process and the development of the argik horizons (Sauer et al., 2009; Quénard et al., 2011). Meanwhile, forms typical of the translocation and accumulation of clay fraction (clay coatings or infillings) were not observed in the studied soils. In addition, the plow horizons did not have an increased clay fraction content compared to the parent materials - so it does not appear to contain even residues of the argik Bt horizons. Because all analyzed calcareous soils in the studied area were located in places most exposed to erosion and were surrounded by eroded clay-illuviated soils, their erosive genesis can certainly be confirmed. Probably they are a result of truncation of clay-illuvial soils pre-developed in these places. The succeeding effect of the erosion was also the low content of organic carbon in Ap horizons (mean - 0,63\%) what according to Józefaciuk and Józefaciuk (1999) is a result of intensive slope

Table 2.

Chemical and physical properties of the studied soils

\begin{tabular}{|c|c|c|c|c|c|c|c|c|c|c|}
\hline \multirow[b]{2}{*}{ Profile } & \multirow[b]{2}{*}{ Horizon } & \multirow[b]{2}{*}{ Dept [cm] } & Corg & $\mathrm{Nt}$ & \multirow[t]{2}{*}{$\mathrm{C} / \mathrm{N}$} & \multicolumn{2}{|c|}{$\mathrm{pH}$} & \multirow{2}{*}{$\begin{array}{c}\mathrm{CaCO}_{3} \\
{[\%]}\end{array}$} & \multicolumn{2}{|c|}{ Color } \\
\hline & & & \multicolumn{2}{|r|}{ [\%] } & & $\mathrm{H}_{2} \mathrm{O}$ & $1 \mathrm{M} \mathrm{KCl}$ & & dry & moist \\
\hline \multirow[t]{2}{*}{1} & Apk & $0-30$ & 0.62 & 0.081 & 8 & 8.1 & 7.9 & 8.3 & 10YR $6 / 3$ & 10YR 4/2 \\
\hline & Ckg & $30-(60)$ & & & & 8.6 & 8.1 & 13.8 & 10YR 7/3 & 10YR 5/4 \\
\hline \multirow[t]{2}{*}{2} & Apk & $0-30$ & 0.49 & 0.064 & 8 & 8.3 & 8.1 & 5.1 & 10YR 5/3 & 10YR 4/3 \\
\hline & $\mathrm{Ck}$ & $30-(60)$ & & & & 8.9 & 8.3 & 12.7 & 10YR $7 / 3$ & 10YR 5/4 \\
\hline \multirow[t]{2}{*}{3} & Apk & $0-30$ & 0.38 & 0.046 & 8 & 8.6 & 8.0 & 9.9 & 10YR 6/3 & 10YR $4 / 4$ \\
\hline & $\mathrm{Ck}$ & $30-(60)$ & & & & 8.7 & 8.0 & 11.6 & 10YR 6/4 & 10YR 5/4 \\
\hline \multirow[t]{2}{*}{4} & Apk & $0-30$ & 0.83 & 0.103 & 8 & 8.0 & 7.5 & 0.4 & 10YR 5/3 & 10YR 3,5/3 \\
\hline & $\mathrm{Ck}$ & $30-(60)$ & & & & 7.8 & 7.1 & 0.4 & 10YR 6/3 & 10YR $4 / 3$ \\
\hline \multirow[t]{2}{*}{5} & Apk & $0-30$ & 0.67 & 0.083 & 8 & 8.5 & 7.9 & 5.8 & 10YR 5/3 & 10YR $4 / 3$ \\
\hline & $\mathrm{Ck}$ & $30-(60)$ & & & & 8.8 & 8.1 & 9.8 & 10YR 6/4 & 10YR 5/4 \\
\hline \multirow[t]{2}{*}{6} & Apk & $0-30$ & 0.46 & 0.057 & 8 & 8.6 & 7.9 & 9.6 & 10YR 5/3 & 10YR $4 / 3$ \\
\hline & $\mathrm{Ck}$ & $30-(60)$ & & & & 8.7 & 7.9 & 12.7 & 10YR 5/3 & 10YR 4/4 \\
\hline \multirow[t]{2}{*}{7} & Apk & $0-30$ & 0.84 & 0.096 & 9 & 8.3 & 7.6 & 3.6 & 10YR 5/3 & 10YR 3,5/3 \\
\hline & $\mathrm{Ck}$ & $30-(60)$ & & & & 8.7 & 7.6 & 13.1 & 10YR 6/3 & 10YR 5/3 \\
\hline \multirow[t]{2}{*}{8} & Apk & $0-30$ & 0.84 & 0.091 & 9 & 8.4 & 7.7 & 7.7 & 10YR 5/3 & 10YR $4 / 3$ \\
\hline & $\mathrm{Ck}$ & $30-(60)$ & & & & 8.6 & 7.7 & 10.6 & 10YR 6/3 & 10YR $4 / 3,5$ \\
\hline \multirow[t]{2}{*}{9} & Apk & $0-30$ & 0.62 & 0.078 & 8 & 8.3 & 7.6 & 9.7 & 10YR $5,5 / 3$ & 10YR $4 / 3$ \\
\hline & $\mathrm{Ck}$ & $30-(60)$ & & & & 8.0 & 7.7 & 6.8 & 10YR $6,5 / 3$ & 10YR 5/4 \\
\hline \multirow[t]{2}{*}{10} & Apk & $0-30$ & 0.71 & 0.086 & 8 & 8.2 & 7.6 & 3.8 & 10YR $4 / 4$ & 10YR 3,5/3 \\
\hline & $\mathrm{Ck}$ & $30-(60)$ & & & & 8.5 & 7.8 & 9.0. & 10YR 6/4 & 10YR 5/4 \\
\hline \multirow[t]{2}{*}{11} & Apk & $0-30$ & 0.59 & 0.074 & 8 & 8.4 & 7.7 & 5.8 & 10YR $5,5 / 4$ & 10YR $4 / 3$ \\
\hline & $\mathrm{Ck}$ & $30-(60)$ & & & & 8.7 & 7.8 & 12.3 & 10YR 6/4 & 10YR 4,5/4 \\
\hline \multirow[t]{2}{*}{12} & Apk & $0-30$ & 0.50 & 0.070 & 7 & 8.4 & 8.0 & 9.3 & 10YR $5,5 / 3$ & 10YR $4 / 4$ \\
\hline & $\mathrm{Ck}$ & $30-(60)$ & & & & 8.7 & 7.9 & 11.7 & 10YR 6/4 & 10YR 5/4 \\
\hline \multirow[t]{2}{*}{13} & Ap & $0-30$ & 0.55 & 0.065 & 8 & 5.6 & 4.8 & - & 10YR 5/3 & 10YR $3 / 3$ \\
\hline & C & $30-(60)$ & & & & 6.5 & 5.4 & - & 10YR $6,5 / 3$ & 10YR 4,5/3 \\
\hline \multirow[t]{2}{*}{14} & Apk & $0-30$ & 0.53 & 0.065 & 8 & 8.2 & 7.7 & 5.99 & 2,5 YR 6/3 & 2,5 YR 4,5/4 \\
\hline & $\mathrm{Ck}$ & $30-(60)$ & & & & 8.6 & 7.6 & 7.26 & 2,5 YR 6/4 & 2,5 YR 4,5/4 \\
\hline \multirow[t]{2}{*}{15} & Apk & $0-30$ & 0.77 & 0.090 & 9 & 8.1 & 7.5 & 2.82 & 10YR $5,5 / 3,5$ & 10YR 3,5/4 \\
\hline & $\mathrm{Ck}$ & $30-(60)$ & & & & 8.2 & 7.5 & 7.87 & 10YR 5/3 & 10YR $4 / 4$ \\
\hline \multirow[t]{3}{*}{16} & Apk & $0-20$ & 0.74 & 0.082 & 9 & 8.4 & 7.9 & 4.20 & 10YR $5 / 3,5$ & 10YR 3,5/3 \\
\hline & $\mathrm{Ck}$ & $20-40$ & & & & 8.4 & 7.7 & 4.58 & 10 YR $5 / 3,5$ & 10YR $4 / 3$ \\
\hline & $2 \mathrm{Ck}$ & $40-(60)$ & & & & 8.9 & 8.4 & 4.50 & 10YR 6,5/4 & 10YR 5/3 \\
\hline
\end{tabular}

- not analyzed 
Fig. 6. Systematic position of eroded calcareous soils

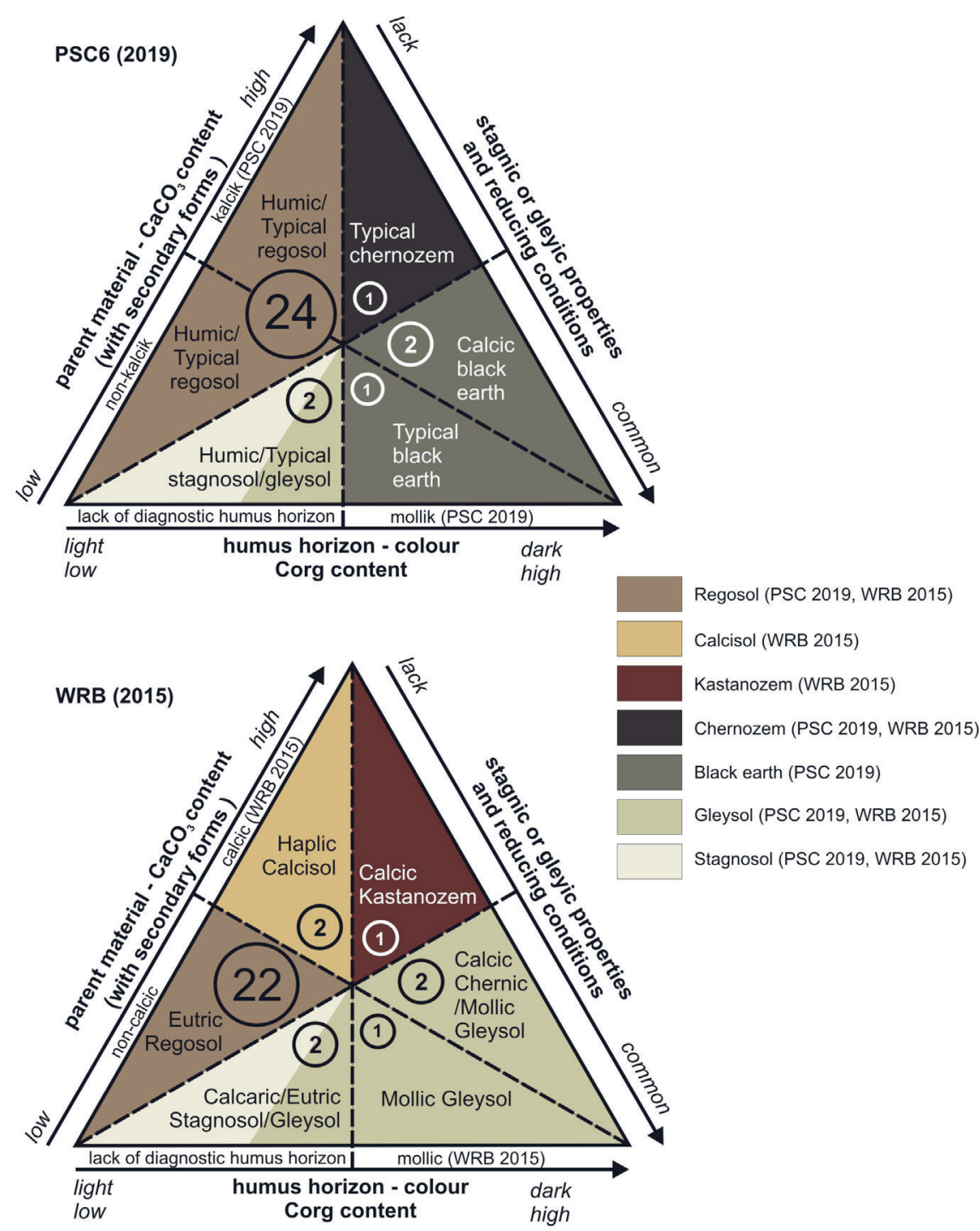

processes and indicate strong soil truncation. Less than $1 \%$ of organic carbon content in eroded Ap-Ck soils was also noted by Podlasiński (2013) in the Wełtyń Plain (2013) and Deumlich et al. (2018) in the north-east of Germany.

Strong truncation of the studied soils affected the lack of diagnostic horizons in the discussed pedons both according to the criteria of Polish Soil Classification (2019) and the international WRB system (IUSS, 2015). With the exception of Profile 1 where a strong influence of groundwater and a shallow occurrence of gleyic properties allowed classify this soil as gleysol (Gleysol in WRB). All other profiles were classified as regosols (Regosols in WRB - Table 3). Despite the fact that Ap horizons have a sufficient thickness, a well-developed soil structure and high base saturation (high $\mathrm{pH}$ values) they could not be considered as diagnostic. In the analyzed cases, the main feature preventing the designation of mollik (mollic in WRB) horizons was the too light color of the Ap horizons. Significant thickness of Ap (resulting from plowing) enabled to identification of humic subtype (PSC, 2019) in fifteen cases of regosols. In WRB names, the Ochric qualifier was used to indicate the presence of humus horizons that do not meet the diagnostic criteria. Their ploughed character was also emphasized by adding the Aric qualifier. The accumulation of calcium carbonate (less than 15\%) and its secondary forms in parent material is also insufficient to meet the diagnostic criteria of kalcik (PSC, 2019) or calcic (IUSS, 2015) horizon. In Polish Soil Classification (2019), the presence of carbonates above $2 \%$ was marked by the calcareous variety within type of regosols which was possible to use in the 14 studied soils. In the WRB nomenclature, in 13 cases where the secondary forms of carbonates occupied more than $5 \%$ of the soil volume, the qualifier Protocalcic was used. The high base saturation (expressed by high $\mathrm{pH}$ values) allowed to use the qualifier Eutric, which due to the lack of other additional features is the most important and the only principal qualifier in all analysed Regosols (IUSS, 2015). It should be added that in the WRB system it was possible to specify in more detail the properties of soils in their names in comparison with the PSC (2019). The loamy texture was emphasized by the use of the Loamic qualifier, and the bedding of the profile 16 with a sandy material of different 
lithogenesis at a depth of $40 \mathrm{~cm}$ - by qualifier Katoarenic and Epiraptic (lithic discontinuity at depth $\leq 50 \mathrm{~cm}$ ). In the case of Gleysol located within the field surrounded by drainage channels, it was also possible to add the qualifier Drainic.

The analyzed soils represent a relatively homogeneous group in terms of classification units. Most of them, despite their low thickness and simple sequence of soil horizons, had well expressed features of pedogenesis (accumulation of humus in surface horizons, significant concentration of secondary carbonates in the parent materials) and presented pedons "on the border" with other classification units. In eight cases (nine in WRB - because of lower diagnostic thickness) almost all criteria of mollik (mollic in WRB) have been met. Moreover in seven profiles the calcium carbonate content in the parent material was high and exceeded over $10 \%$, which brings them close to kalcik (PSC, 2019) or calcic (IUSS, 2015) horizon. Review of archival materials (master's theses) and previously published papers focused on the erosional changes of soil cover within young glacial morainic areas and elaborated in the Department of Soil Science and Landscape Management of Nicolaus Copernicus University in Torun allowed for a broader view on the systematic position of eroded soils containing calcium carbonate in plow horizons. Additional 15 profiles (Table 4) were analysed - together 30, because non-calcareous Profile 13 was not further taken into consideration.

Calcareous soils not influenced by groundwater or without strong stagnation of rainwater and with Ap-Ck sequence of genetic horizons which did not meet the diagnostic criteria - typical/ humic regosols PSC (2019) or Eutric Regosols (IUSS 2015) represented the most common pedons (22 profiles). In the two other cases (Ramowska, 2016; Rataj, 2012) the presence of kalcik/calcic horizons with primary and secondary carbonates content $>15 \%$ has been noted just under the plow horizons. According to WRB

Table 3.

Systematic position of investigated soils

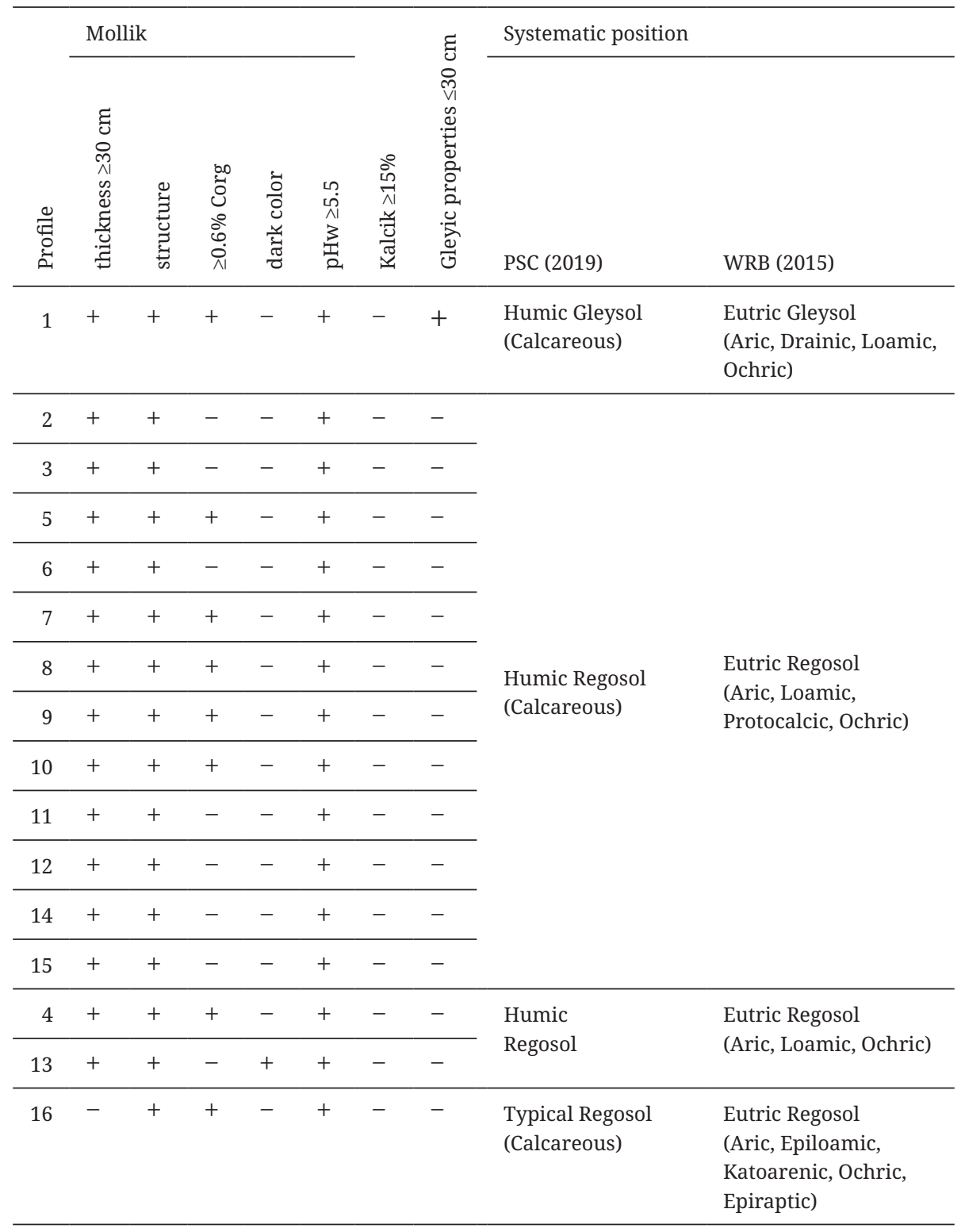


Table 4.

Systematic position of calcareous soils based on a literature review

\begin{tabular}{|c|c|c|c|c|c|c|c|}
\hline \multirow[b]{2}{*}{$\dot{z}$} & \multirow[b]{2}{*}{ Site } & \multirow{2}{*}{$\begin{array}{l}\stackrel{y}{0} \\
\stackrel{0}{0}\end{array}$} & \multirow{2}{*}{ 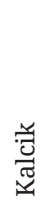 } & \multirow{2}{*}{ 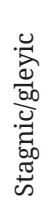 } & \multicolumn{2}{|l|}{ Systematic position } & \multirow[b]{2}{*}{ Reference } \\
\hline & & & & & PSC (2019) & WRB (2015) & \\
\hline 1 & Ślesin, Krajna morainic plateau & + & + & - & Typical Chernozem & $\begin{array}{l}\text { Calcic Kastanozem } \\
\text { (Aric, Loamic, Pachic) }\end{array}$ & Świtoniak et al. (2018) \\
\hline 2 & Zbójno, Dobrzyń Lakeland & - & + & - & \multirow{10}{*}{$\begin{array}{l}\text { Humic/Typical } \\
\text { Regosol } \\
\text { (Calcareous) }\end{array}$} & \multirow{2}{*}{$\begin{array}{l}\text { Haplic Calcisol } \\
\text { (Aric, Loamic, Ochric) }\end{array}$} & Rataj (2012) \\
\hline 3 & Bocień, Chełmno Lakeland & - & + & - & & & Ramowska (2016) \\
\hline 4 & \multirow{2}{*}{ Gaj, Brodnica Lakeland } & - & - & - & & \multirow{8}{*}{$\begin{array}{l}\text { Eutric Regosol } \\
\text { (Aric, Loamic, } \\
\text { Protocalcic, Ochric) }\end{array}$} & Świtoniak (2014) \\
\hline 5 & & - & - & - & & & Świtoniak et al., (2014) \\
\hline 6 & Sumowo, Brodnica Lakeland & & & - & & & Świtoniak et al. (2013) \\
\hline 7 & Wąbrzeźno, Chełmno Lakeland & - & - & - & & & Izydorski (2016) \\
\hline 8 & Jedwabno, Chełmno Lakeland & - & - & - & & & Ramowska (2016) \\
\hline 9 & Papowo Toruńskie, Chełmno Lakeland & - & - & - & & & \multirow{2}{*}{ Szuliński (2017) } \\
\hline 10 & Gronówko, Chełmno Lakeland & - & - & - & & & \\
\hline 11 & Zbójno, Dobrzyń Lakeland & - & - & - & & & Dąbrowski et al. (2018) \\
\hline 12 & Wielka Łąka, Chełmno Lakeland & + & + & + & \multirow[t]{2}{*}{ Calcic black earth } & \multirow{2}{*}{$\begin{array}{l}\text { Calcic Chernic/ Mollic } \\
\text { Gleysol (Aric, Drainic, } \\
\text { Loamic) }\end{array}$} & Zieliński (2014) \\
\hline 13 & Kamionki Małe, Chełmno LAkeland & + & + & + & & & Szuliński (2017) \\
\hline 14 & Wielka Łąka, Chełmno Lakeland & + & - & + & Typical black earth & $\begin{array}{l}\text { Mollic Gleysol (Aric, } \\
\text { Drainic, Loamic, } \\
\text { Protocalcic) }\end{array}$ & Zieliński (2014) \\
\hline 15 & Sumówko, Brodnica Lakeland & - & - & + & Typical stagnosol & $\begin{array}{l}\text { Calcaric Stagnosol } \\
\text { (Endoarenic, Aric, Ochric) }\end{array}$ & Mendyk et al. (2014) \\
\hline
\end{tabular}

(IUSS, 2015) such pedons were classified as Calcisols, whereas in PSC (2019) for such soils it is not possible to mark the presence of kalcik horizons in the rank of a separate type or subtype of regosols. It can be only highlighted by the use of calcareous variety. The need to raise the rank of this attribute to the subtype in regosols (analogously like e.g. in black earths type) should be widely discussed in the future. In one place, the soil was additionally characterized by the presence of the mollik (mollic in WRB), which in combination with the kalcik (calcic in WRB), entitles to put it in the chernozem type (PSC, 2019) or according to rules of WRB (IUSS, 2015) - Kastanozem reference soil group (Chernozems in WRB must have even better developed than mollic - the chernic horizon). The occurrence of this type of soil in highly eroded places was resulted from inhibition of erosion and "rebuilding" of the humus horizon (Świtoniak et al., 2018). The discussed chernozem (PSC 2019) was located on the upper border of the meadow (in the past it was plowing area) where grass vegetation stopped the erosion and led to the accumulation of organic carbon and change color to dark enough for criteria of mollik horizon. All mentioned soils (with or without diagnostic horizons) occupied the upper slopes and summits of moraine hills of the Chełmno
(Izydorski, 2016; Ramowska, 2016; Szuliński, 2017), Dobrzyń (Rataj, 2012; Dąbrowski et al., 2018) or Brodnica Lake District (Świtoniak et al., 2013, 2014; Świtoniak, 2014) and they were surrounded by the "rings" of eroded clay-illuvial soils with exposed argik (argic, WRB) horizons on the surface. On aerial photographs, in the "background" or "matrix" of the soil cover outside the dark brown Bt rings, light gray or brown colors mainly occur indicating relatively small amounts of humus in plow horizons what is related to good natural drainage of area (Fig. 4; Świtoniak et al., 2013).

The next 5 profiles represent soils with strong gleyic or stagnic properties (Ap-Ckg). The poor natural drainage of the areas with these soils was reflected in aerial photographs by the dark gray or even almost black color of soils in "background" surrounding bright contours of carbonate soils and dark brown rings of Bt outcrops (Fig. 4; Świtoniak et al., 2013). This indicates a substantial amount of humus accumulated in soils located in depression with conditions of insufficient aeration and periodical waterlogging (Fig. 4; Białousz et al., 1978). Although studied Ap-Ckg soils resemble morphologically fully formed, non-eroded semihydrogenic soils such as gleysols or black earths, their erosive shallowing leading to exposure on the surface calcareous material is indisput- 
able. They occupied relatively low hills at the foot of which young colluvial material has been found. In one case stagnic properties were found and the soil was assigned to stagnosols (PSC, 2019; IUSS, 2015). The factor that hinders the outflow of rainwater was the shallow presence of a low permeable kame material rich in calcium carbonate (Mendyk et al., 2014). The four remaining soils were significantly influenced by groundwater. According to WRB (IUSS, 2015), they were classified to the Gleysol reference group. After applying the criteria adopted in PSC (2019) only one profile belonged to gleysols. In the other three profiles, the presence of mollik horizons was recorded, thanks to which they met the criteria of black earths. In this group, the two pedons were also characterized by a significant accumulation of calcium carbonate (> 15\%), thus representing a subtype of calcic black earths.

\section{Summary and conclusions}

The obtained results allow to draw the following conclusions:

- the contours of the studied calcareous soils can be determined on the basis of areas with light brown color of humus horizons, surrounded by dark brown rings - corresponding to outcrops of Bt horizons of eroded clay-illuvial soils;

- investigated calcareous soils, were truncated by erosion and have a simple morphology that is generally limited to two horizons: Ap-Ck in areas with good natural drainage and Ap-Ckg in areas with periodic water saturation;

- in areas with good natural drainage, the examined calcareous soils are characterized by lack of diagnostic horizons and mainly represent regosols both in terms of Polish Soil Systematics (2019) and the international WRB system (2015). In some profiles, a significant concentration of secondary carbonates and $\mathrm{CaCO}_{3}$ content higher than $15 \%$ allowed for classifying the soil as Calcisol according to WRB. In one case, due to the inhibition of erosive processes and the development of mollik horizon (over kalcik horizon), transformation of weakly developed soil in chernozem (PSC 2019) or according to criteria of WRB - Kastanozem was confirmed.

- in moraine uplands with restricted natural drainage, calcareous soils were mostly classified as black earths or less often gleysols or stagnosols (PSC, 2019). According to WRB, these soils are mostly Gleysols, much less frequently - Stagnosols.

Studies on the properties of eroded calcareous soils and the use of various cartographic materials in determining their range of occurrence require further continuation. It is necessary to develop a procedure for automatically determining the contours of these soils. An interesting issue would be to diagnose the relationship between the color of their surface horizons and the content of calcium carbonate, organic carbon or texture. A thorough comparative analysis of calcareous soils location in combination with detailed terrain models would also help in determining the morphometric parameters of the surfaces conditioning the occurrence of such a strong stage of soil truncation.

\section{Acknowledegements}

The authors would like to thank dr. Adam Michalski for help and care during laboratory analysis.

\section{References}

Bednarek, R., Prusinkiewicz, Z. 1997. Geografia gleb, Warszawa, 287 ss. Bednarek, R., Szrejder B., 2004. Struktura pokrywy glebowej zlewni reprezentatywnej Strugi Toruńskiej, [w:] Kejna, M., Uscka, A., [red.] Zintegrowany Monitoring Środowiska Przyrodniczego. Funkcjonowanie i monitoring geosystemów w warunkach narastającej antropopresji. Biblioteka Monitoringu Środowiska, Toruń, 243-252.

Bednarek, R., Jankowski, M., 2006. Gleby. [w:] Toruń i jego okolice: monografia przyrodnicza, Wydawnictwo Uniwersytetu Mikołaja Kopernika, Torun

Bednarek, R., Dąbrowski, M., Świtoniak, M., 2009. Antropogeniczne przekształcenia pokrywy glebowej gminy Jeżewo. Zeszyty Problemowe Postępów Nauk Rolniczych 540, Warszawa, 139-146.

Białousz, S., 1978. Zastosowanie fotointerpretacji do wykonywania map stosunków wodnych gleb. PTG, Prace Komisji Naukowych 35, 1-143.

Białousz, S., Mirosz, K., Simla, M., 1978. Wpływ wilgotności gleby na zróżnicowanie tonu zdjęcia lotniczego [w:] Fotointerpretacja w geografii, 12, 111-116.

Buringh, P., 1970. Introduction to the study of soils in tropical and subtropical regions PUDOC, Wageningen.

Chudecki, Z., 1960. Materiały do badań nad erozją gleb na Pomorzu Zachodnim, Roczniki nauk rolniczych 74, F2, 417-432.

Chudziak, W., 1990. Wczesnośredniowieczny zespół osadniczy w rejonie Gronowa, woj. toruńskie (w świetle badań w latach 1987-1989), [w:] Studia nad osadnictwem średniowiecznym ziemi chełmińskiej. Gronowski mikroregion osadniczy. Inst. Archeol. i Etnogr. UMK w Toruniu, Toruńskie Towarzystwo Kultury, Torun, 44-68.

Dąbrowski, M., Bednarek, R., Piziur, A., Wilk M., 2018. Agricultural areas in the moraine plateau with glacial curvilineations (Dobrzyń Lakeland, Poland). [In:] Świtoniak, M., Charzyński, P., [Eds.] Soil sequences atlas IV. Machina Druku, Toruń, 213-228.

De Alba, S., Lindstrom, M., Schumacher, T.E., Malo D.D., 2004. Soil landscape evolution due to soil redistribution by tillage: a new conceptual model of soil catena evolution in agricultural landscapes. Catena 58, 77-100. https://doi.org/10.1016/j.catena.2003.12.004

Deumlich, D., Schmidt, R., Sommer, M., 2010. A multiscale soil-landform relationship in the glacial-drift area based on digital terrain analysis and soil attributes. Journal of Plant Nutrition and Soil Sciences 173, 843-851. https://doi.org/10.1002/jpln.200900094

Deumlich, D., Ellerbrock, R.H., Frielinghaus, Mo. 2018. Estimating carbon stocks in young moraine soils affected by erosion. Catena 162, 51-60. https://doi.org/10.1016/j.catena.2017.11.016

Dreibrodt, S., Lubos, C., Terhorst, B., Damm, B., Bork, H.-R., 2010. Historical soil erosion by water in Germany: scales and archives, chronology, research perspectives. Quaternary International, 222, 80-95. https:// doi.org/10.1016/j.quaint.2009.06.014

Evans, R., 1993. On assessing accelerated erosion of arable land by water. Soils and Fertilisers 56 (11), 1285-1293.

Gacki, T., Gołębiewski, R., 1977. Fotointerpretacja erozji gleb obszarów młodoglacjalnych na przykładzie zlewni górnej Raduni. Fotointerpretacja w geografii 10, 102-113.

IUSS Working Group WRB, 2015. World Reference Base for soil resources 2014. International soil classification system for naming soils and creating legends for soil maps. Update 2015. World Soil Resources Report No. 106. FAO, Rome.

Izydorski, Ł., 2016. The impact of anthropogenic denudation on trophism of soils of morainic plateau in the vicinity of Wąbrzeźno. Master's 
thesis manuscript - under the supervision of Renata Bednarek. Department of Soil Science and Landscape Management, NCU in Torun (in Polish).

Józefaciuk, C., Józefaciuk, A., 1996. The erosion mechanisms and methodological indicators for the research on erosion. Environmental Monitoring Library, (in Polish).

Józefaciuk, A., Józefaciuk, C., 1999. Ochrona gruntów przed erozją. Wyd. IUNG Puławy, 109 ss.

Kabała, C., Charzyński, P., Chodorowski, J., Drewnik, M., Glina, B., Greinert, A., Hulisz, P., Jankowski, M., Jonczak, J., Łabaz, B., Łachacz, A., Marzec, M., Mendyk, Ł., Musiał, P., Musielok, Ł., Smreczak, B., Sowiński, P., Świtoniak, M., Uzarowicz, Ł., Waroszewski, J., 2019. Polish Soil Classification, 6th edition - principles, classification scheme and correlations. Soil Science Annual, 70, 2, 71-97. https://doi.org/10.2478/ ssa-2019-0009

Kittel, P., 2014. Slope deposits as an indicator of anthropopressure in the light of research in Central Poland. Quaternary International 324, 34-55. https://doi.org/10.1016/j.quaint.2013.07.021

Klimowicz, Z., Uziak, S., 2001. The influence of long-term cultivation on soil properties and patterns in an undulating terrain in Poland. Catena 43, 177-189. https://doi.org/10.1016/S0341-8162(00)00162-4

Koćmit, A., Chudecka, J., Podlasiński, M., Raczkowski, B., Roy, M., Tomaszewicz T., 2001. The spatial variability of soil on eroded slope in morain area of West Pomerania. Folia Universitatis Agriculturae Stetinensis. 217 Agricultura (87), 97-102.

Kobierski, M., 2013. Morfologia, właściwości oraz skład mineralny gleb płowych zerodowanych w wybranych obszarach morenowych województwa kujawsko-pomorskiego. Wydawnictwa Uczelniane Uniwersytetu Technologiczno-Przyrodniczego, Bydgoszcz.

Kondracki, J., 2009. Geografia regionalna Polski. Wydawnictwo Naukowe PWN, Warszawa.

Leopold, M., Völkel, J., 2007. Colluvium: definition, differentiation, and possible suitability for reconstructing Holocene climate data. Quaternary International 162 (163), 133-140. https://doi.org/10.1016/j. quaint.2006.10.030

Marcinek, J., Komisarek, J., 2004. Antropogeniczne przekształcenia gleb Pojezierza Poznańskiego na skutek intensywnego użytkowania rolniczego. Wydaw. Akademii Rolniczej im. Augusta Cieszkowskiego, Poznań.

Martinez-Casasnovas, J.A., Ramos, M.C., 2009. Soil alteration due to erosion, ploughing and levelling of vineyards in north east Spain. Soil Use and Management 25, 183-192. https://doi.org/10.1111/j.14752743.2009.00215.x

Mendyk, Ł., Markiewicz, M., Świtoniak, M., 2014. Catchments of disappearing lakes in glacial meltwater landscapes (Brodnica Lake District). [In:] Świtoniak, M., Charzyński, P., [Eds.] Soil sequences atlas. Wydawnictwo Naukowe UMK, Toruń: 93-107.

Munsell Soil Colour Charts, 2000. GreagMacbeth, New Windsor.

Niewiarowski, W., 1959. Glacial forms and types of deglaciations on the moraine plateau of Chełmno (Bydgoszcz district). Studia Soc. Sci. Torun. Section C. 1. 4. Toruń (In Polish with English summary).

Niewiarowski, W., Weckwerth, P., 2006. Geneza i rozwój rzeźby terenu, [w:] Toruń i jego okolice: monografia przyrodnicza. Wydawnictwo Uniwersytetu Mikołaja Kopernika, Toruń.

Novák, T., Árendás, T., Świtoniak, M., 2018. Soils of an undulating, cultivated loess plateau in North Mezőföld, Central Hungary. [In:] Świtoniak M., Charzyński P., [Eds.] Soil sequences atlas IV. Machina Druku, Toruń, 113-122.

Paluszek, J., 1994. Wpływ erozji wodnej na strukturę i wodoodporność agregatów gleb płowych wytworzonych z lessu. Roczniki Gleboznawcze - Soil Science Annual 45, 3/4, 21-31.

Paluszek, J., 2010. Zmiany pokrywy glebowej pod wpływem erozji. Prace i Studia geograficzne. 45, 279-294.
Penížek, V., Zádorová, T., Němeček, K., 2018. Soils of hilly loess region in Ždánice Forest, south-east Czechia. [In:] Świtoniak M., Charzyński P., [Eds.] Soil sequences atlas II. Machina Druku, Toruń: 115-126.

Pindral, S., Świtoniak, M. 2017. The usefulness of soil-agricultural maps to identify classes of soil truncation. Soil Science Annual 68 (1), 2-10.

Podlasiński, M., 2013. Wpływ denudacji antropogenicznej na zróżnicowanie pokrywy glebowej i jej przestrzenną strukturę w rolniczym krajobrazie morenowym, Wydawnictwo Uczelniane Zachodniopomorskiego Uniwersytetu Technologicznego w Szczecinie, Szczecin.

Polish Soil Classification, 2019. Polskie Towarzystwo Gleboznawcze, Komisja Genezy Klasyfikacji i Kartografii Gleb. Wydawnictwo Uniwersytetu Przyrodniczego we Wrocławiu, Polskie Towarzystwo Gleboznawcze, Wrocław - Warszawa.

Przewoźna, B. 2012. Przekształcenia gleb w wyniku denudacji antropogenicznej interpretowane na podstawie map gleboworolniczych, ortofotomap i badań terenowych. Czasopismo Prace Komisji Krajobrazu Kulturowego, Komisja Krajobrazu Kulturowego Polskiego Towarzystwa Geograficznego, 148-156

Quénard, L., Samouëlian, A., Laroche, B., Cornu, S., 2011. Lessivage as a major process of soil formation: a revisitation of existing data. Geoderma 167-168, 135-147. https://doi.org/10.1016/j.geoderma.2011.07.031

Ramowska, D., 2016, The influence of soil conditions for diversification of cereal yields in the landscape of undulating morainic plateaus. Master's thesis manuscript - under the supervision of Piotr Hulisz. Department of Soil Science and Landscape Management, NCU in Torun (in Polish).

Rataj, P., 2012, Characteristics of the immediate catchment area of soil around the kattle-hole near Zbójenko. Master's thesis manuscript under the supervision of Renata Bednarek. Department of Soil Science and Landscape Management, NCU in Torun (in Polish).

Sauer, D., Schülli-Maurer, I., Sperstad, R., Sørensen, R., Stahr, K. 2009. Albeluvisol development with time in loamy marine sediments of southern Norway. Quaternary International 209, 31-43. https://doi. org/10.1016/j.quaint.2008.09.007

Sinkiewicz, M., 1998. The development of anthropogenic denudation in central part of northern Poland. Wydawnictwo Uniwersytetu Mikołaja Kopernika, Toruń. 103 ss (in Polish with English abstract).

Solon, J., Borzyszkowski, J, Bidłasik, M., Richling, A, Badora, K, Balon, J, Brzezińska-Wójcik, T, Chabudziński, Ł., Dobrowolski, R, Grzegorczyk, I, Jodłowski, M., Kistowski, M., Kot, R., Krąż, P., Lechnio, J., Macias, A., Majchrowska, M., Malinowska, E., Migoń, P., Myga-Piątek, U., Nita, J., Papińska, E., Rodzik, J., Strzyż, M., Terpiłowski, S., Ziaja, W., 2018. Physico-geographical mesoregions of Poland: Verification and adjustment of boundaries on the basis of contemporary spatial data. Geographia Polonica 91(2), 143-170. https://doi.org/GPol.0115

Sommer, M., Schlichting, E. 1997. Archetypes of catenas in respect to matter a concept for structuring and grouping catenas. Geoderma 76, 1-33. https://doi.org/10.1016/S0016-7061(96)00095-X

Szuliński, M., 2017. Diversity of eroded soils of Chełmno and Brodnica Lakeland. Master's thesis manuscript - under the supervision of Marcin Świtoniak. Department of Soil Science and Landscape Management, NCU in Toruń (in Polish).

Świtoniak, M., 2014. Use of soil profile truncation to estimate influence of accelerated erosion on soil cover transformation in young morainic landscapes, North-Eastern Poland. Catena 116, 173-184. https://doi. org/10.1016/j.catena.2013.12.015

Świtoniak, M., 2015. Issues relating to classification of colluvial soils in young morainic areas (Chełmno and Brodnica Lake District, northern Poland). Soil Science Annual. 66 (2), 57-66. https://doi.org/10.1515/ ssa-2015-0020

Świtoniak, M., Markiewicz, M., Bednarek, R., Paluszewski, B., 2013. Application of aerial photographs for the assessment of anthropogenic denudation impact on soil cover of the Brodnica Landscape Park plateau areas. Ecological Questions 17, 101-111. http://dx.doi. org/10.12775/ecoq-2013-0020 
Świtoniak, M., Charzyński, P., Mendyk, Ł., 2014. Agricultural areas within hummocky moraine plateaus of Poland (Brodnica Lake District). [In:] Świtoniak M., Charzyński P., [Eds.] Soil sequences atlas. Wydawnictwo Naukowe UMK, Toruń, 77-91.

Świtoniak, M., Dąbrowski, M., Łyszkiewicz, A., 2015. The Influence of Human-induced Erosion on the Soil Organic Carbon Stock in Vineyards of Fordon Valley. Polish Journal of Soil Science 48, 2, 197-211.

Świtoniak, M., Mroczek, P., Bednarek, R., 2016. Luvisols or Cambisols? Micromorphological study of soil truncation in young morainic landscapes - Case study: Brodnica and Chełmno Lake Districts (North Poland). Catena. 136, 583-595. https://doi.org/10.1016/j.catena.2014.09.005

Świtoniak, M., Hulisz, P., Jaworski, T., Pietrzak, D., Pindral, S., 2018. Soils of slope niches in the Torun-Eberswalde ice-marginal valley. [In:] Świtoniak M., Charzyński P., [Eds.] Soil sequences atlas II. Machina Druku, Toruń, 157-175.

Turski, R., Paluszek, J., Słowińska-Jurkiewicz, A., 1987. Wpływ erozji na fizyczne właściwości gleb wytworzonych z lessu. Roczniki Gleboznawcze - Soil Science Annual, 38(1), 37-49.

Turski, R., Paluszek, J., Słowińska-Jurkiewicz, A., 1991. Wpływ rzeźby terenu na stopień zerodowania i właściwości fizyczne gleb lessowych, [w:] Z. Mazur, S. Pałys, W. Grodzieński [red.], Erozja gleb i jej zapobieganie, Wyd. AR, Lublin, 47-62.

Uggla, H., Mirowski, Z., Grabarczyk, S., Nożyński, A., Rytelewski, J., Solarski, H., 1968. The water erosion process in hilly areas of north-eastern

part of Poland. Soil Science Annual 18 (2), 415-446 (in Polish with English summary).

Van Oost, K., Van Muysen, W., Govers, G., Heckrath, G., Quine, T.A., Poesen, J., 2003. Simulation of the redistribution of soil by tillage on complex topographies. European Journal of Soil Science 54, 63-76. https://doi. org/10.1046/j.1365-2389.2003.00470.x

Wójcik, G., Marciniak, K., 1987a. Thermal conditions in central part of the North Poland in the years 1951-1970. Acta Universitatis Nicolai Copernici Geografia 20, 29-50 (in Polish).

Wójcik, G., Marciniak, K., 1987b. Precipitation in the central part of northern Poland in years 1951-1970. Acta Universitatis Nicolai Copernici Geografia 20, 51-69 (in Polish).

Wysota, W., 1993. Model kształtowania rzeźby subglacjalnej w środkowo-wschodniej części Pojezierza Chełmińsko-Dobrzyńskiego. Mat. II Seminarium: Geneza, litologia i stratygrafia utworów czwartorzędowych, Poznań.

Zieliński, G., 2014. The application of aerial photographs in mapping of semi-hydrogenic, chernozemic soils in the Chełmińskie Lake District. Master's thesis manuscript - under the supervision of Renata Bednarek. Department of Soil Science and Landscape Management, NCU in Torun (in Polish, abstract in English).

Žížala, D., Juřicová, A., Zádorová, T., Zelenková, K., Minařík, R., 2019. Mapping soil degradation using remote sensing data and ancillary data: South-East Moravia, Czech Republic. European Journal of Remote Sensing 52, S1, 108-122. https://doi.org/10.1080/22797254.2018.1482 524

Delimitacja konturów, właściwości i pozycja systematyczna gleb zawierających węglan wapnia w poziomach ornych w obszarach młodoglacjalnych

\author{
Słowa kluczowe \\ Ortofotomapy \\ Erozja gleb \\ Gleby węglanowe \\ Regosole
}

\section{Streszczenie}

Erozja gleb prowadzi do spłycenia profilu glebowego i zmian właściwości fizycznych, chemicznych oraz cech morfologicznych gleby. Odsłanianie głębszych partii gleby wywołuje też zmianę barwy poziomów powierzchniowych, co znajduje swoje odzwierciedlenie na zdjęciach lotniczych. Szczególnie narażone na przekształcenia erozyjne są obszary rolnicze, w których intensywna działalność człowieka prowadzi do wzmożenia naturalnych procesów stokowych oraz przemieszczania materiału glebowego przez maszyny i narzędzia rolnicze, co nazywane jest denudacją antropogeniczną. Obszar badań - gmina Chełmża (powiat toruński) leży w obrębie wysoczyzny morenowej pagórkowatej i płaskiej, zbudowanej z glin zwałowych ostatniego zlodowacenia. Intensywne użytkowanie rolnicze połączone ze znacznymi deniwelacjami terenu spowodowało ogłowienie gleb płowych, które dominują na analizowanym obszarze. Największe przekształcenia można zaobserwować na szczytach pagórków wysoczyznowych, gdzie poziom orny analizowanych gleb wymieszany jest ze skałą macierzystą bogatą w węglan wapnia. W celu wyznaczenia zasięgu gleb, które zawierają węglan wapnia w poziomach ornych przeanalizowano ogólnodostępne ortofotomapy oraz materiały kartograficzne w postaci map topograficznych i numerycznego modelu terenu. Na podstawie przyjętego klucza fotointerpretacyjnego wyznaczono ponad 700 konturów gleb potencjalnie zasobnych w całym profilu w węglan wapnia, stanowiących około 1\% powierzchni analizowanego obszaru. Przy ich wyznaczaniu wzięto pod uwagę: 1) bardzo jasną barwę poziomów powierzchniowych, 2) występowanie w miejscach eksponowanych na erozję - na wierzchowinach pagórków i w obrębie wypukłych stoków, 3) otoczenie pierścieniami silnie zerodowanych gleb płowych odznaczających się barwą ciemnobrązową poziomów ornych i wskazującą na odsłonięcie poziomów argik. Badania terenowe i laboratoryjne pozwoliły na weryfikację wyznaczonych zasięgów gleb zerodowanych zasobnych w węglan wapnia. Potwierdziły one wysoką przydatność ogólnodostępnych zdjęć lotniczych, ponieważ 96\% wyznaczonych na ich podstawie konturów reprezentowało gleby bardzo silnie zerodowane (Apk-Ck) i zawierało węglan wapnia w poziomach ornych. Średnia zawartość $\mathrm{CaCO}_{3}$ w poziomach ornych wyniosła 6,1\%. Poziomy próchniczne nie spełniały kryteriów barwy i (lub) zawartości węgla organicznego wymaganego dla poziomów mollik, a skały macierzyste miały zbyt małą zawartość węglanu wapnia dla wydzielenia poziomów kalcik. Według Systematyki gleb Polski z 2019 r. większość analizowanych gleb można zaklasyfikować jako regosole. W jednym przypadku ze względu na silne oglejenie, profil glebowy zaklasyfikowano jako glebę gruntowo-glejową. Przegląd archiwalnych materiałów dotyczących gleb zerodowanych bogatych w węglan wapnia wskazuje też na możliwość wystąpienia w grupie tych gleb czarnoziemów, czarnych ziem i gleb opadowo-glejowych zawierających poziomy mollik i/lub kalcik. 